\title{
EFFECTS OF ORGANIC WASTES ON OLIVE MINERAL NUTRITION AND ITS INFLUENCE ON FRUIT QUALITY. PRELIMINARY RESULTS FOR MACRONUTRIENTS
}

Monge, E. and Val, J.,

Estación Experimental de Aula Dei (C.S.I.C.).

Apdo. 202

50080 Zaragoza

Spain

Tel: +34/976/576511 Fax: +34/976/575620 E-Mail: emongw@eead.csic.es

Espada, J.L., Orús, F. and Betran, J.

Diputación General de Aragón. Departamento de Agricultura y Medio Ambiente.

Apt.727

50080 Zaragoza

Spain

Keywords: Olea europaea; fertilization; olive nutrition; olive quality; pig slurry and wastes

\begin{abstract}
$\underline{\text { Abstract }}$
The effect of pig slurry fertilization on two olive (Olea europaea L. cv. Empeltre) groves has been studied for one season. The dosage of landsprayed slurry was 15 and $30 \mathrm{~m}^{3} \mathrm{ha}^{-1}$ for a non-irrigated olive grove, which was in a bearing year and 30 and $60 \mathrm{~m}^{3} \mathrm{ha}$ for an irrigated grove in a non-bearing year. The macronutrient seasonal trend, both young (less than a year old) and old (older than one ycar), was studied from February until December. The evolution curves of the macronutrients from young and old leaves showed the same tendency, although the concentrations in young leaves were usually greater than old leaves, except for calcium. The macronutrient evolution curves of olive fruits have been also studied. The results showed that this kind of fertilization did not lead to significant increases in mineral leaf concentrations in this first year trial of slurry fertilization.
\end{abstract}

\section{$\underline{\text { Resumen }}$}

Se ha estudiado el efeclo que produce la fertilización, durante el primer año, con cstiércol fluido de porcino (EFP) en dos olivares (Olea europaea L. cv. Empeltre), uno de secano y el otro de regadio. Las dosis de EFP fueron 15 y $30 \mathrm{~m}^{3} \mathrm{ha}^{-1}$ para el olivar de secano, que ese año estaba con cosecha y 30 y $60 \mathrm{~m} 3 \mathrm{ha}-\mathrm{l}$ para el olivar de regadio, que estaba en vecería. El estudjo se ha basado en la variabilidad de las concentraciones de los macronutrientes de hojas y de aceitunas desde febrero hasta diciembre. El estudio de la tendencia estacional que presentan los macronutrientes se ha realizado tanto en hoja joven (con menos de un año de edad) como en hojas adultas (con más de un año de edad). La evolución estacional que mostraron los macronutrientes fue muy similar en hojas adultas y jóvenes, aunque las concentraciones en las hojas jóvenes eran normalmente mayorcs que en las hojas adultas, salvo el calcio.

Las concentraciones de los distintos macronutrientes, no respondieron a las dosis de EFP, ya que no se observaron diferencias significativas entre un mismo elemento y las diferentes dosis aplicadas. Por lo tanto, podemos afirmar que EFP no produjo ningún efecto fertilizante en el olivar durante el primer año de aplicación. 


\section{Introduction}

The olive growing area in Aragon (Spain) is approximately 50,300 ha, which represents $2 \%$ of Spanish olive growing areas (MAPA, 1994). Olive production oscillates around $27,300 \mathrm{t}$ (average of the last years), equivalent to 5,800 $\mathrm{t}$ of olive oil. The crop is important in certain areas of Teruel (Bajo Aragón-Belchite, with the 'Empeltre' variety), in Huesca (zone of Barbastro, with the varieties 'Empeltre, Arbequina, Verdual and Negral') and in Zaragoza (zone of Borja with the variety 'Empeltre' and in Almunia with the variety 'Arbequina').

The use of wastes in agriculture, for saving energy, is increasing. Studies have been carried out on the composting cycle using a wide range of organic materials (Dubois, 1985), but the use of wastes as fertilizer in olive groves has been little investigated.

Barbiris et al. (1988) made several experiments with encouraging results, on containcr-grown olive trees, using several types of wastes. Tattini et al. (1990) used grape-urban sludge on container-grown Leccino olive trees. Morell (1996) used pig slurry as fertilizer on Arbcquina olive groves.

The organic fertilization with manure is a widespread method used to maintain and improve soil fertility. Recently, the traditional solid manure has been replaced by slurry since on most farms conventional straw beds are no longer used in the stables and piggeries. The faeces and urine are cleared out with running water and collected and stored in a pit. The organic manures and slurries are usually applied to the stubble after harvesting arable land, prior to cultivation, or applied directly on the land of different tree groves. Some farmers tend to compare slurries to solid manures, and they usually use it improperly, which can lead to serious problems for the crops and for the environment.

According to Bould (1972), the level of fertilization has a great influence on the mineral concentration of the leaves, particularly at specific development stages, whereas Gonzalez (1972), among others, showed the importance of bearing and non-bearing years on leaf element concentrations.

The aim of these experiments was to study the evolution of leaf-macronutrients in olive trees and assess the fertilization potential of pig slurry applied at various rates in the first year of application. In this paper data are shown from the first growing season (1997) of two experiments that will last four years (1997-2000).

\section{Materials and methods}

Two adult olive orchards (Olea europaea L. cv. 'Empeltre', around 85 year old trees), one flood irrigated and one non-irrigated, are being used for the experiments. The olive groves are planted on calcareous soils, at a planting density of 85 trees per hectare.

Each trial consists of 2 treatments of slurry and these are compared to an untreated control. The treatments have been applied in a completely randomized blocks design, with 3 replications, and the experimental unit consisted of two trees.

The treatments in the non-irrigated orchard were: 15 and $30 \mathrm{~m}^{3} \mathrm{ha}^{-1}$ year ${ }^{-1}$ and were applied at the end of February 1997. In the irrigated orchard, the treatments were 30 and $60 \mathrm{~m}^{3} \mathrm{ha}^{-1} \mathrm{year}^{-1}$ applied in two different dates: half the dosage at the end of February and the other half at the beginning of April.

Old and young leaves (about 100), around the olive trees canopy, were picked in different dates from February until November.

To determine the mineral concentration, the olive tree leaves, with their petioles, were carefully washed with a soft brush and liquid soap (1\%) and rinsed with tap and deionized water to eliminate surface contamination. The $\mathrm{N}$ determination was analysed according to the Kjeldahl digestion method (Jones, 1991(a)). Dry ashing was carried oul following the Pinta and DeWele method (1975). Calcium and $\mathrm{Mg}$ were determined by atomic absorption spectroscopy, $\mathrm{K}$ by flame emission and $\mathrm{P}$ by the vanodomolybdophosphoric method. The resulting data were expressed as percentage of 
dry tissue for $\mathrm{Ca}, \mathrm{K}, \mathrm{Mg}, \mathrm{N}$ and $\mathrm{P}$.

The pig slurry was analysed according to Calvo (1996). Its composition was (kg $\left.\mathrm{m}^{-3}\right) \mathrm{N} 5.4, \mathrm{P}_{2} \mathrm{O}_{5} 4.8, \mathrm{~K}_{2} \mathrm{O} 5.2, \mathrm{CaO} 3.6$ and $\mathrm{MgO} 1.3$

\section{Results}

The seasonal fluctuation of the macroelement concentrations is shown in figures 1 to 6. The different symbols that are showed in the scasonal curves of the figures are the mean values of the three repetitions that there is by treatment, the standard deviations are not represented in the figures. Data from young and adult leaves at each date of sampling were analyzed independently. The results of ANOVA never showed significant differences due to the treatments, for which further analysis were never made.

Figure 1 ( $a$ and $b$ ) shows that the young leaves have a higher concentrations of total $N$ than the old leaves. The first sample of young leaves, in the non-irrigated grove, could be harvested in April, while the same sample in the irrigated grove, in a nonbearing year, was harvested in May. According to the curves shown in this figure, leaf-N concentration is practically constant from September to May, while from May to August it shows a gradual decrease. The different dosages of applied slurry seem not to have any effect on the concentrations of leaf- $\mathrm{N}$ because non significant differences were found, for each date of analysis, among slurry treatments.

The $\mathrm{P}$ concentrations of young leaves have a higher concentration that adult ones (figure $2 \mathrm{a}$ and $\mathrm{b}$ ) and the biggest concentration of this element was in the first young leaf sample (April). The concentrations of this element in young and mature leaves show a slight increment, from bloom (May) until September. The dosages of applied slurry seem not to affect the concentration of $\mathrm{P}$ in leaves, similar to $\mathrm{N}$.

The young olive leaves also have a higher $\mathrm{K}$ concentration that adult leaves (figure $3 \mathrm{a}$ and $\mathrm{b}$ ). The concentrations of this element, in the two leaf types, showed a slight increase from July to September. Non significant differences were found among dosages of landsprayed slurry.

The flucluation of the concentrations of $\mathrm{Ca}$ are plotted in figure $4 \mathrm{a}$ and $\mathrm{b}$. The young leaves had lower concentrations than the mature ones and the seasonal curves, in hoth kinds of leaves, seem to show a slight but constant increase during the season. It is necessary to point out that significant differences exist among the concentrations between olive groves with crop load (graphic 4 a) and thosc without crop load (4 b), data nonshown. Results of the dosages of applied slurry did not show significant differences.

Figures $5 \mathrm{a}$ and $\mathrm{b}$ indicate the seasonal variation in concentrations of $\mathrm{Mg}$. The young leaves had lower concentratjons than the mature leaves. The curves, for both kinds of leaves, show a slight but constant increment until the month of September, after which concentrations declined. The concentrations of leaf-Mg, from leaf samples harvested in non-irrigated olive groves (fig. 5 a), did not show significant differences between young and adult leaves. The concentrations of young leaves from irrigated without crop loads (fig. 5 b) had lower concentrations than adult leaves. No significant effect was observed on leaf $\mathrm{Mg}$ concentrations with the application of different slurry dosages.

In figure $6 \mathrm{a}$ and $\mathrm{b}$ the seasonal macroelement variation for olive fruit from nonirrigated and bearing olive groves are indicated. Significant differences do not exist in the nitrogen concentrations, throughout the fruit sampling, although the concentrations of this element tends to diminish (fig 6 a). However, the concentration of $\mathrm{K}$ increases from fruit set until September. The highest concentration of $\mathrm{K}$ coincided with the time that the fruit began to change colour. Figure $6 \mathrm{~b}$ shows the seasonal patterns for $\mathrm{P}, \mathrm{Ca}$ and $\mathrm{Mg}$, which are stable until September and from then on decrease. According to results shown in this figure, we can affirm that, in the first year of fertilization with pig slurry, differences are not observed in concentrations of different macroelements. 


\section{Discussion}

The information about fertilization or seasonal variation in leaves from olive trecs has usually been obtained from young olive groves. In this paper, the data refer to two mature plantations, irrigated and non-irrigated, more than 85 years of age. Neither olive grove. showed any visual symptoms of nutritional stress and thcy were in perfect phytosanitary conditions.

If we kcep in mind the recommended critical levels of mineral deficiency (Beutel et al., 1983; Jones et al., 1991 (b); Femandez-Escobar, 1998), for $\mathrm{N} \int 1.5$, for the P $\int 0.1$, for $\mathrm{K} \int 0.8$, for $\mathrm{Ca} \int 0.1$ and for $\mathrm{Mg} \int 0.1$, our results lead to some conclusions. We can conclude that the criterion for defining a mineral deficiency in an olive crop depends on the time when the samples were harvested and if they are young or old leaves.

Although most of the leaf mineral concentrations of these olive groves are apparently sufficient, according to our figures, it is obvious that the critical levels of mineral deficiency have to be different for young and adult leaves. While mineral concentrations of young leaves seem to be within the sufficiency range, the adult leaves show concentrations below this range at some periods.

Other researchers (Bouat et al., 1955; Ferrcira, et al., 1984; Jordao et al., 1994) have already studied the seasonal variations of olive leaf macroelements. The fluctuation trend for leaf- $\mathrm{N}$ and $\mathrm{P}$, described by these researchers, during the autumn-winter period remains constant, but decreases from the month of April onwards reaching a minimum in August. The pattern for $K$ is described as a continuous decrease from the full bloom of olive trees. For $\mathrm{Ca}$, they have described two periods, during the first period the concentration remains constant until July, upon new growth after which Ca concentration is also stable. They have also described that $\mathrm{Mg}$ concentration curve increases from bloom to October. The fluctuation curves shown in our figures ( 1 to 5), are adapted to the criterions exposed by these researchers, although in some cases there are slight discrepancies. Our figures also demonstrate that mineral concentrations in young leaves are different than those of older leaves and that these results agree with the results found by Bouat et al., 1955; Ferreira, et al., 1984; Jordao et al., 1994.

Although the olive groves were landspread with pig slurry in February, we did not expect any response to this kind of fertilization in the first year, because the macroclement concentrations, according to sampling time, did not show significant differences. Nevertheless the data obtained for the K-concentrations (figure 3-b) seem to indicate that there is a positive response to slurry application, because there are significant differences between different rates of landsprayed pig slurry and the level of concentration in young leaves.

Figure 6 shows the evolution of the concentrations of $\mathrm{N}-\mathrm{P}-\mathrm{K}$ in olive fruits, from July to November. According to these results shown, we could interpret that that there is no influence from the pig slurry applied and the macroelement concentrations in olive fruit. Jordao and Lietao (1990) analysed the composition of fruits coming from 50 olive tree cultivars growing in Portugal. The mean values $(\mathrm{N}=1.27 ; \mathrm{P}=0.20$ and $\mathrm{K}=1.92)$ are slightly higher than those shown in figure 6 , but our results are within their data limits, with the exception of the $\mathrm{K}$ values in the July sample .

All these results shown in different figures, seem to indicate that neither olive groves showed any evidence that they had been fertilized with different rates of pig slurry and only the leaf-K concentration in young leaves seemed to be affected.

\section{Acknowledgements}

Research work is supported by the Diputación General de Aragón. Spain (Projects PCA1394 and P29/97 I). The authors are grateful to M.A.Gracia for her collaboration in the analytical work. 


\section{$\underline{\text { References }}$}

Barbiris, R., Bartolini, G., Nappi, P., Tattini, M. 1988. Chemical characteristic of the substrate, fertigation and olive growth. Acta Horticulturae, 221: 161-166

Beutel, J., Uriu, K., Lilleland, O. 1983. Leaf analysis for Califomia deciduous fruits. Soil and plant tissue testing in California., 1879., California University

Bouat, A., Renaud, P., Dulac, J. 1955. Etude sur la physiologie de la nutrition de l' olivier (quatrième memoire). Ann. Agron. Serie A., 6: 635-650.

Bould C. 1972. Mineral nutrition of fruit plants. Procedings 18th of the International Horticultural Congress, IV: 15 1-154

Calvo, M. 1996. Estudio analítico de los residuos de una explotación intensiva de ganado porcino. Tesis Doctoral., Zaragoza, Facultad de Ciencias. Universidad de Zaragoza (Spain)

Dubois, J.P. 1985. Evolution des paramètres physico-chimiques et biologiques. In: Recherche interdisciplinaire sur la preparation de bouses $\mathrm{d}^{\prime}$ épuration et sur leur utilization en agriculture. Station de Recherches Agronomiques de Changins., Changins

Fernandez-Escobar, R. 1998. Fertilización. El cultivo del olivo. $2^{\circ}$ edición.. Barranco, D., Fernandez-Escobar, R. \& Rallo, L.: 237-257., Junta de Andalucía y Ediciones MundiPrensa.Spain

Fcrreira, J., García, A., Frias, L., Fernández, A. 1984. Los nutrientes N, P, K en la fertilización del olivar. X Aniversario Red Coopcraliva Europea de Investigación en Oleicultura, Cordoba. Spain

Gonzalez G.F. 1972. Aspectos fisiológicos en la nutrición del olivar de mesa variedad "Manzanillo de Sevilla": ciclo y metabolismo de nutrientes. $3^{\circ}$ Coll. Eur. Medit. Control Fert. Plant. Cult:: 509-534, Budapest

Jones, B. 1991a. Kjcldahl Method of Nitrogen Determination. Micro-Macro Publishing, 183 Paradisc Blvd., Suite 108. Athens, Georgia 30604

Jones, B. Jr., Wolf, B., Mills H.A. 1991. Tables of interprerative values. Plant Analysis Handbook. Jones, B. Jr., Wolf, B. \& Mills H.A.: 162, Micro-Macro Publishing, Inc

Jordao, P.V., Dias, J.C.S., Calouro, F., Duarte, M.L. 1994. Effect of fertilization on the leaf macronutrient concentrations of olive tree. Acta Horticulturae, 356: 197-201.

Jordao, P.V., Lietao, F. 1990. The olive's mineral composition and some parameters of quality in fifty olive cultivars grown in Portugal. Acta Horticulturae, 286: 461-464.

MAPA (Ministerio de Agricultura, Pesca y.Alimentación.) 1994. Anuario de Estadística Agraria., Madrid.Spain

Morell, S. 1996. Ensayo de fertilización con purines del olivar de la varicdad Arbequina en secano. Fruticultura Prolesional., 83; 102-105., Barcelona. Spain, Agro Latino

Pinta, M., DeWele, G. 1975. Etalons vegetaux pour l'analyse foliare. Lc côntrole de l'alimentation des plantes cultivees.. Kozma, P.: 159-172., Budapest, Akademiai Kiado

Tattini, M., Bertoni, P., Traversi, M.L., Nappi, P. 1990. Waste materials as potting media in olive pot production. Acta Horticulturae, 286: $121-124$ 


\section{Figures}
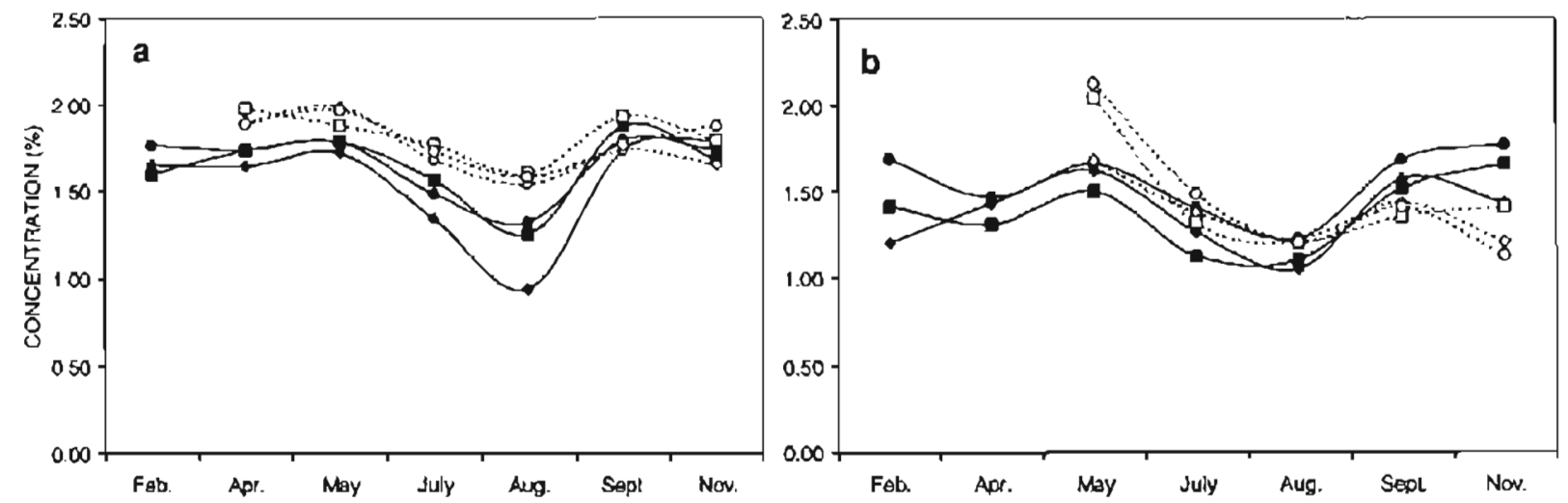

1. Seasonal changes of $N$ in young (dotted line) and old leaves (solid line) of nonirrigate in bearing year (a) and irrigate in non-bearing year (b) olive groves, cv. Empeltre. The lines with rhombus represent the seasonal variation without slurry application, with squares symbolize intermediate and with circles represent the biggest slurry dosages. Non-significant differences have been found for each date of analysis
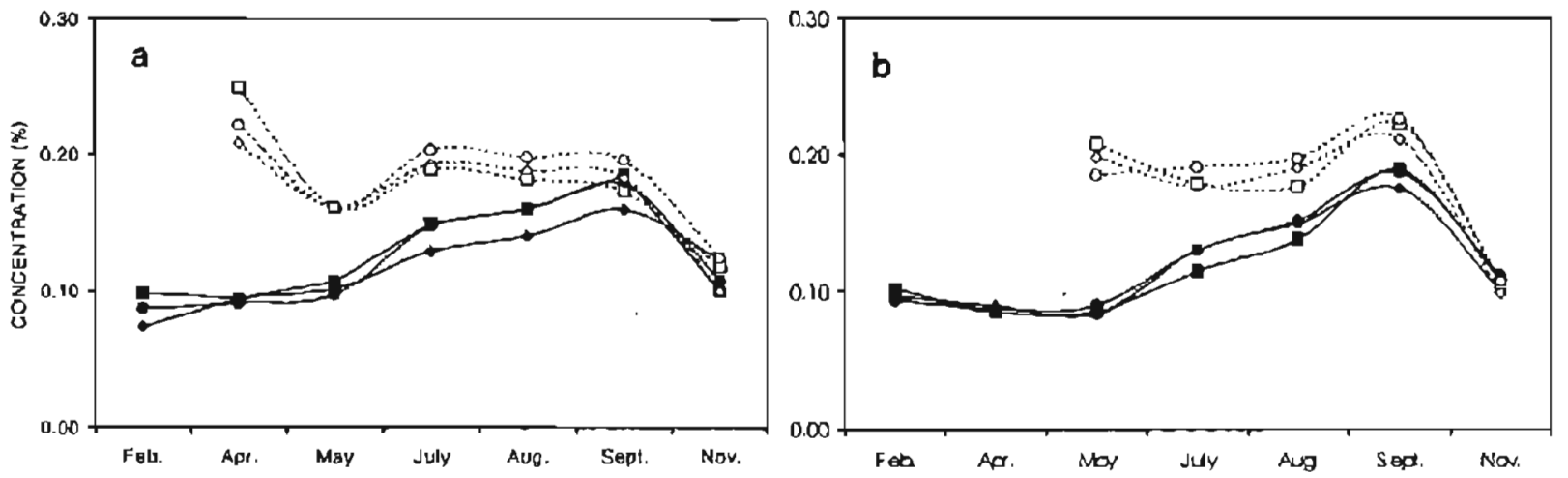

2. Seasonal changes of $P$ in young (dotted line) and old leaves (solid line) of nonirrigate in bearing year (a) and irrigate in non-bearing year (b) olive groves, cv. Empeltre. The lines with rhombus represent the scasonal variation without slurry application, with squares symbolize intermediate and with circles represent the biggest slurry dosages. Non-significant differences have been found for each date of analysis 

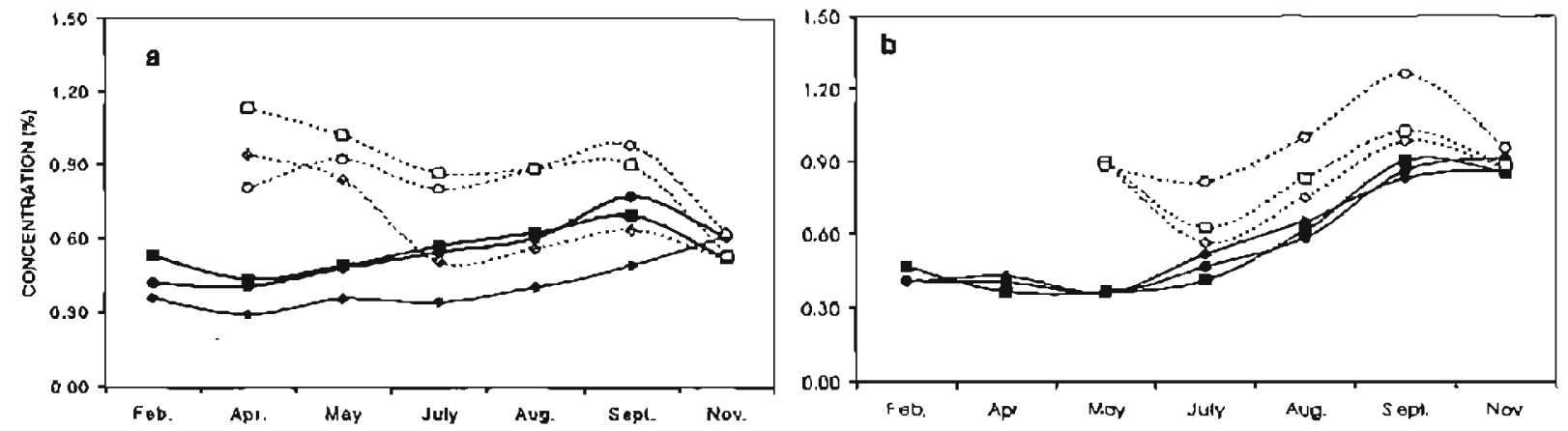

3. Seasonal changes of $\mathrm{K}$ in young (dotted line) and old leaves (solid line) of nonirrigate in bearing year (a) and irrigate in non-bearing year (b) olive groves, $c v$. Empeltre. The lines with rhombus represent the seasonal variation without slurry application, with squares symbolize intermediate and with circles represent the biggest slurry dosages. Non-significant differences have been found for each date of analysis.
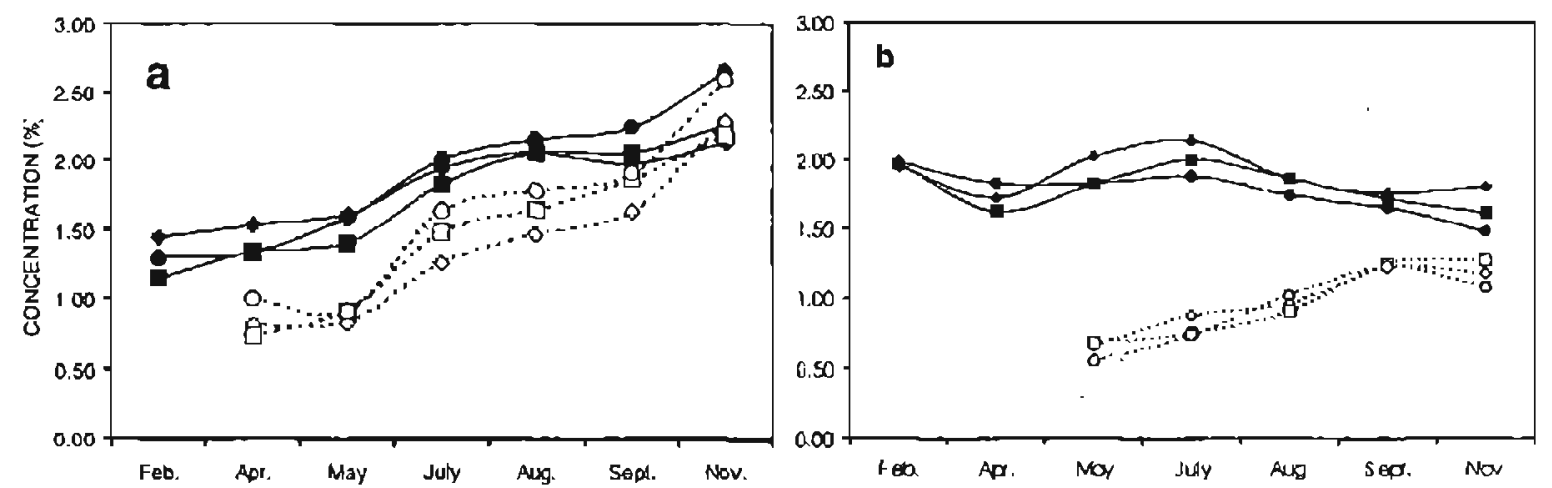

4. Seasonal changes of $\mathrm{Ca}$ in young (dotted line) and old leaves (solid line) of non-irrigate in bearing year (a) and irrigate in non-bearing year (b) olive groves, cv. Empeltre. The lines with rhombus represent the seasonal variation without slurry application, with squares symbolize intermediate and with circles represent the biggest slurry dosages. Non-significant differences has been found for each date of analysis 

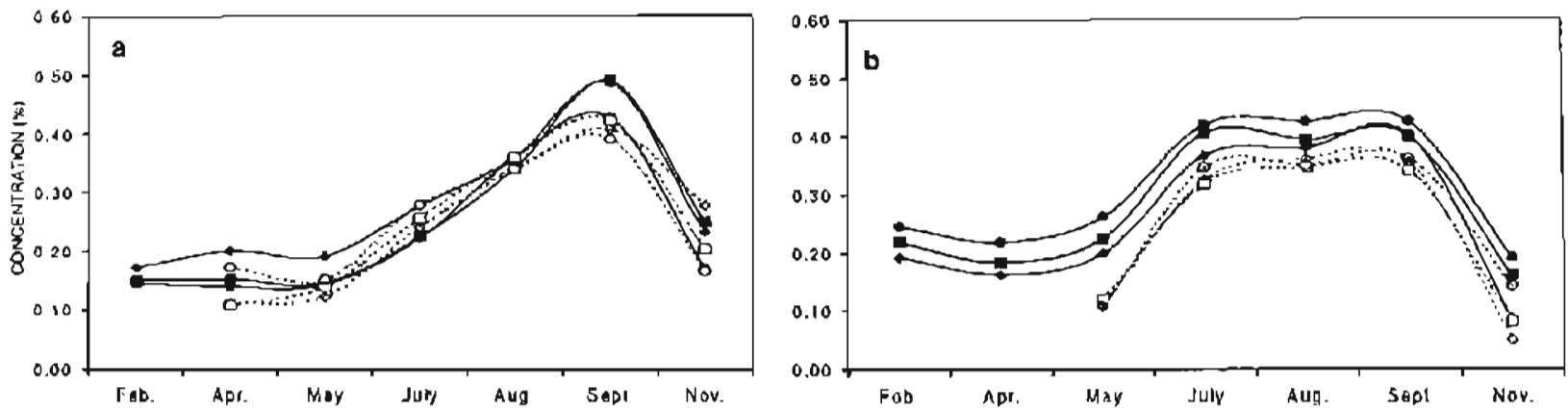

5. Seasonal changes of $\mathrm{Mg}$ in young (dotted line) and old leaves (solid line) of non-irrigate in bearing year (a) and irrigate in non-bearing year (b) olive groves, cv. Empeltre. The lines with rhombus represent the seasonal variation without slurry application, with squares symbolize intermediate and with circles represent the biggest slumy dosages. Non-significant differences has been found for each date of analysis.
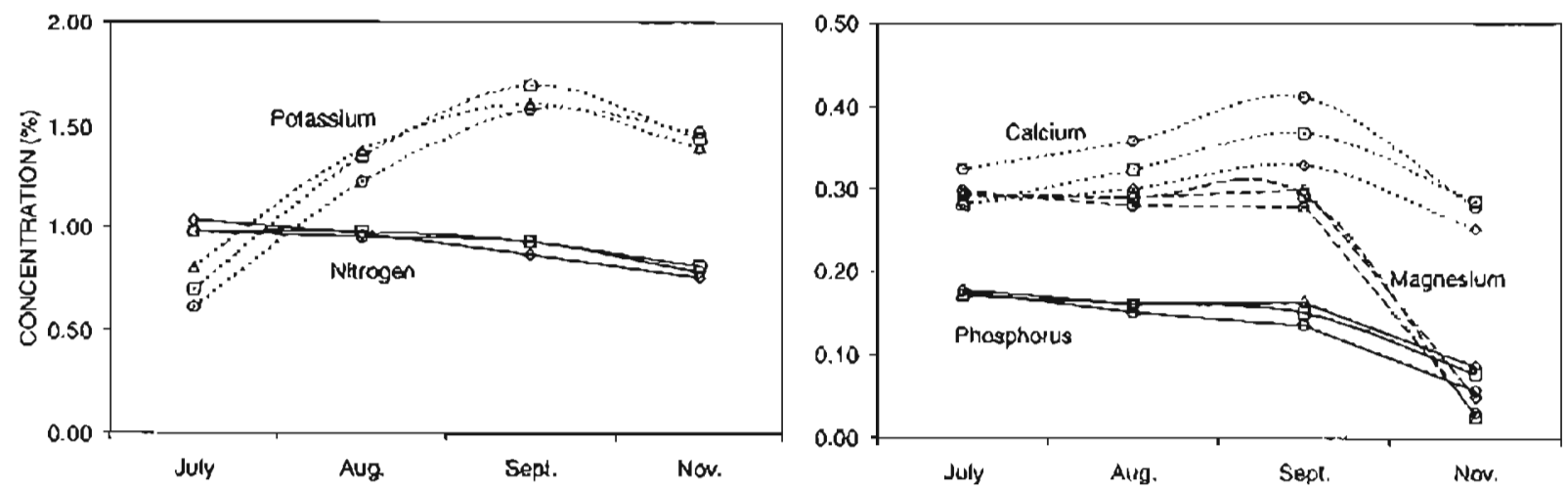

6. Seasonal changes of macronutrient concentration in olive fruits, cv. Empeltre.

The lines with rhombus represent the seasonal variation without slurry application, with squares symbolize intermediate and with circles represent the biggest slurry dosages. Non-significant differences has been found for each date of analysis. 